\section{Social engineering and Emiratization in the United Arab Emirates}

\section{Social engineering and \\ Emiratization}

University of Sharjah, Sharjah, United Arab Emirates, and

Mohammad Habibur Rahman

Mohammed Bin Rashid School of Government, Dubai, United Arab Emirates

\begin{abstract}
Purpose - The purpose of this paper is to analyze the rationale for using social engineering as a tool to impact the nationalization of workforce in the United Arab Emirates (UAE).

Design/methodology/approach - Interpretative and exploratory approaches have been employed for this research. Accordingly, the study has extensively reviewed government documents, reports of international organizations and relevant academic literature, including journal articles, conference papers and unpublished dissertations.

Findings - The findings show that the UAE Government has initiated multiple policies and programs to enhance participation of indigenous Emiratis in the burgeoning labor market which has been hitherto dominated by the expatriates. However, while the Emiratization programs are on the verge of fulfilling the targets in the public sector job market, significant gaps exist between the targets and accomplishments in the private sector, causing policy concern.

Originality/value - This paper links theoretical insights from the social engineering model used in the social sciences research to analyze the dynamics of workforce nationalization. The study will be helpful to inform further empirical research in this area.
\end{abstract}

Keywords Workforce nationalization, Emiratization, Social engineering, United Arab Emirates

Paper type Research paper

\section{Introduction}

Emiratization, a policy to enhance the participation of Emirati citizens in the job market, has received considerable attention from the national political leadership in the United Arab Emirates (UAE). The extremely low rate of Emirati citizens' participation in the private sector job market adds to the policy dilemma confronting the UAE Government. This policy dilemma has stemmed from the unique social and economic conditions prevailing in the country.

The discovery of oil and gas in the late 1960s and their soaring price in the 1970s facilitated the influx of the expatriate workforce in various fields in the UAE. With massive revenues in hand, the UAE leadership embarked on grand projects for infrastructural development in different sectors. Given the small size of its local population, the UAE Government did not have any other option but to engage workers from different parts of the world in both the public and private sectors. Furthermore, the policy of economic diversification to tap the opportunities of globalization pursued since the 1990s created strong demand for a more skilled (and unskilled) workforce, particularly in the service sector.

(C) Abu Elias Sarker and Mohammad Habibur Rahman. Published in Public Administration and Policy. Published by Emerald Publishing Limited. This article is published under the Creative Commons Attribution (CCBY 4.0) license. Anyone may reproduce, distribute, translate and create derivative works of this article (for both commercial and non-commercial purposes), subject to full attribution to the original publication and authors. The full terms of this license may be seen at http://creativecommons. org/licences/by/4.0/legalcode
Received 29 February 2020 Revised 14 April 2020 Accepted 4 June 2020 
However, with the modernization of education, a large pool of indigenous educated workforce entered the job market. The public sector at both the federal and local government levels attracted the burgeoning young and employable Emiratis. Because of the superior compensation package, short working hours, pension schemes and other fringe benefits, the public sector has always been the destination of the local educated workforce in all the seven emirates. The private sector job market continues to be dominated by the expatriate workforce. It remains less attractive to the local indigenous workforce. Besides, the emergence of an eco-system leading to smart government and technology/innovation-driven services, the workforce remains at the centre of ongoing policy discourse in the UAE. With the growing number of unemployed young people and prospective future needs in the diversified economy, the national leadership has been pursuing a policy, known as Emiratization, to absorb the unemployed national young people in the thriving private sector.

Despite diverse policies and programs, the goals of Emiratization remain unfulfilled, particularly in the private sector. Emiratization is now considered a challenging issue, while the solutions to the problems have not provided expected results. This paper aims at exploring the dynamics of Emiratization by analyzing the underlying contextual factors, policies and programs, the outcomes and the challenges. This paper adopts the 'social engineering model' to reflect on the policies and programs implemented by the UAE Government.

\section{Emiratization: unfolding the policy dilemma in a unique context}

Emiratization implies the nationalization of the workforce that focuses on a more visible Emirati workforce in all service and other sectors, which necessarily would lead to a gradual replacement of expatriate workforce by the local Emirati citizens. Emiratization is an issue that needs some explanation in the backdrop of the small size of the local population, the abundance of natural resources, the post-oil economic diversification strategy, as well as the integration of the local economy into the global economic structure. This requires a reorientation of the collective mindset of the local citizenry.

At this moment, it is essential to reflect briefly on the context of the UAE. The UAE came into existence in 1971 with the federation of seven Emirates - Abu Dhabi, Dubai, Sharjah, Ajman, Ras Al Khaimah, Fujaira and Umm Al Quwain. It was a tribal society and the livelihood of Emiratis depended on agriculture, livestock, craft and pearling. The discovery of oil and gas gradually changed the structure of production. Notably, the rise of oil prices following the Arab-Israel war in 1973 poured a significant amount of revenues into the national exchequer, facilitating massive investment in physical and social infrastructure. Over the last 48 years, the structure of the economy has witnessed massive transformations with the service economy replacing the oil economy as the major contributor to national gross domestic product (GDP) (Government of the United Arab Emirates, 2018).

Politically, the UAE is a federal constitutional monarchy with a blend of tradition and modernity. A Federal Supreme Council governs the federal affairs made up of the Rulers assisted by the office of the President, the Council of Ministers, the judiciary and the parliament (Federal National Council). Each Emirate has a Ruler who assumes absolute power. The federal constitution has clearly demarcated the responsibilities of the federal and local governments.

Before the discovery of oil, pearl trading, maritime commerce, limited agricultural and livestock activities and small traditional manufacturing activities supported UAE's subsistence economy (Government of the United Arab Emirates, 2018). But within four decades, the country has transformed itself into a modern developed country. Debates abound on the causes of such rapid socio-economic transformations (Jones, 2017; Hvidt, 2009). 
With the blessing of abundant natural resources and visionary leadership, the UAE has placed itself as one of the prosperous countries in the world, and there is international comparative data to corroborate this. Table 1 indicates some socio-economic indicators, showing that the UAE residents enjoy one of the highest per capita incomes in the world. The level of economic and social development has also risen sharply over the years.

Advancements in the socio-economic spheres have also been associated with remarkable improvements in administration and governance. Comparative data from the World Bank's good governance indicators, World Economic Forum's Global Competitive Index, and the World Bank's 'Doing Business' indicate tremendous progress in public service delivery, business climate, and institutional development (Khalid and Sarker, 2019).

The reality is that the segmented labor market has made the Emiratis a minority. While the job prospects in the public sector are on the verge of saturation, there is no other option for policymakers but creating job opportunities for the unemployed Emiratis in the burgeoning private sector. However, Emiratization entails a broader meaning. It is not merely about creating job opportunities but also about repositioning Emiratis in the thriving social and economic arena of the country.

Demographic imbalance has remained a significant feature in the UAE over a long period. The World Bank (2020) estimated a population size of 9.63 million, of which expatriates account for around 88.50 percent and 11.50 percent indigenous Emiratis. The influx of expatriates commenced in the 1960s, gained momentum in the 1970s and has continued to increase following the country's transformation into a diversified economy.

The trends in the demographic composition of the Emirati people have not been merely compatible with the escalating economic activities. In 1975, the total size of the population was 558,000, of which 356,000 were expatriates and 202,000 Emiratis. In 2018, the total population jumped to 9.50 million with 8.447 million expatriates. "Emiratis are a minority in their own country, comprising two of every ten in the population" (Al-Ali, 2008, p. 1). As economic activities triggered by the oil boom and diversifications increased, so did the inflow of expatriates. Though Emiratis constitute 11.5 percent of the total population, they represent less than 10 percent of the active labor force (Daleure, 2017). Studies show the rising trend of unemployment among educated Emiratis. Sabry and Zaman (2013) estimated 14 percent, while another set of data provides an unpleasant picture of the rate of unemployment among the active Emirati population. The Federal Competitiveness and Statistics Authority (2018) estimated 6.6 percent, 29.1 percent, 23.8 percent, 15.7 percent and 14.6 percent unemployed Emiratis in the age groups of 15-19, 20-24, 25-29, 30-34 and 35-39 respectively.

\begin{tabular}{lccc}
\hline Indicators & 2005 & 2010 & 2019 \\
\hline GDP (million current US\$) & 182978 & 289787 & 382575 \\
GDP per capita (current US\$) & 39955.3 & 35037.9 & 40698.8 \\
Human Development Index (HDI) & 0.825 & 0.836 & 0.866 \\
HDI Rank & 95 & 100 & 35 \\
Expected years of Schooling (years) & & & 13.6 \\
Mean years of schooling (years) & $76.3 / 74.1$ & $77.3 / 75.1$ & $78.2 / 76.1$ \\
Life expectancy at birth (females/males, years) & 9 & 7.7 & 6.5 \\
Infant mortality rate (per 1 000 live births) & & $101.5 / 101.5$ & $108.9 / 112.8$ \\
Education: Primary gross enrol. ratio (f/m per 100 pop.) & & $93.0 / 98.6$ \\
Education: Secondary gross enrol. ratio (f/m per 100 pop.) & 40 & 68 & 94.8
\end{tabular}

Sources: United Nations (2020); United Nations Development Programme (2019)

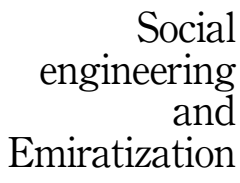

175 
PAP

23,2

It is not merely the low number of the Emirati people that affected their ability to keep pace with increased economic activities. Socio-cultural factors, coupled with the education infrastructure and the need for increased flow of foreign direct investment, have also contributed to the asymmetric demographic situation.

While there is the need to correct labor market imbalance, the ownership of national prosperity and the preservation of national identity have also been significant drivers of the Emiratization policy. In an era of globalization, the erosion of cultural values has been a common phenomenon globally. UAE's political leadership is well aware of this trend and determined to preserve old national culture.

Another way to look at the Emiratization policy is through the integration of citizenry with spectacular socio-economic development as they may feel they have been dwarfed by the expatriates (Davidson, 2009).

\section{Social engineering for Emiratization}

Social engineering, as an analytical model, has been in the realm of social science for a long time. The model is generic and employable by different types of organizations and also the state. In its simplest term, social engineering is planned intervention by the state to orchestrate social change and mould the behavioral patterns of the members of a society. According to Alexander and Schmidt (1996, p.1), social engineering means "arranging and channeling environmental and social forces to create a high probability that effective social action will occur."

The deployment of social engineering in the jurisdiction of the state can be traced back to the twentieth century. As the model is applied in the societal arena, it cannot be value-neutral. Accordingly, different types of regimes have adopted this model. Very often, it is misconstrued as it was used by authoritarian states such as the former Soviet Union, Maoist China, and Nazi Germany. The political projects orchestrated by authoritarian states prompted many neoclassicists, including Popper (2012), to criticise the social engineering model. However, scholarly works also contend that social engineering was not only nurtured on the soil of the authoritarian states; many advanced democratic and post-colonial states also embraced this model (Podgórecki et al., 1996). In fact, many of these states nullified the obsession of the scholars with the ascendency of the market forces and stimulated social and economic transformations (Zafarullah and Huque, 2012).

Abuse of the model for gratifying the ill purposes of the autocratic regimes did not preclude the possibility of deploying the model to pursue well-managed social and economic agenda by the state. There is a large body of literature that vindicates many non-democratic post-colonial states for accomplishing social and economic transformations through wellplanned social engineering. The rise of South Korea, Singapore, and Malaysia bear testimony to this fact (Yeung, 2014; Vu, 2007). Social engineering efforts associated with the orthodox, old-fashioned authoritarianism focus on the ideological manipulation of citizenry with disregard to individualism, personal autonomy and the cultural fabric of society (Jones, 2015; Alexander and Schmidt, 1996). As opposed to the coercive mechanisms associated with the archaic dictatorial system, liberal social engineering has sneaked into many contemporary illiberal democracies. Notionally, liberal social engineering can only flourish in democratic societies that guarantee fundamental rights - property, civil and political. Jones observes:

By liberal social engineering, I mean social engineering efforts that conform to liberal ideals of character. In political theory, these include, but are not limited to, individualism, personal autonomy, critical thinking, secularism, and tolerance or open-mindedness. Such ideals may be imparted to citizens through education (civic and otherwise), public symbolism, and other mechanisms of social engineering (Jones, 2015, p.27). 
An intriguing question remains whether liberal social engineering can creep into illiberal democracies. Nevertheless, many illiberal democracies have embraced liberal ideals, albeit with some compromises. While many Middle Eastern countries have advanced economically, their social engineering policies vary based on the precepts of liberalism.

\section{Liberal social engineering in the UAE: key steps}

The UAE is one of the gulf countries that attained considerable progress in social and economic spheres. The abundance of oil resources coupled with well-planned state intervention paved the way for massive transformations during the past few decades. Despite enormous prosperity, there exist several social and economic challenges. A segmented labor market with considerable presence of the expatriate workforce, growing unemployment among the local Emiratis and relative detachment of the local Emiratis from the flourishing economy have made the national leadership rethink the overall state strategies for integrating local Emiratis into the national economy and employment market. Accordingly, several policy and strategic attempts have been made to bring out the local Emiratis from the safety nets and to help them counter the competitive labor market. Leaving aside a few liberal ideals such as personal autonomy, the UAE political leadership has implemented some path-breaking reforms in different spheres. The most prominent ones include the introduction of a Western-style education system, Emiratization policy, the 'National Innovation Strategy' and the 'National Program for Advanced Skills.' In 2015, the UAE observed the 'Year of Innovation' and the leaders attempted to inspire the Emiratis to be innovative. The following year was declared as the 'Year of Reading' and they were motivated to develop the habit of reading (Jones, 2017).

Concerning educational reform, the UAE Government made the English language as the medium of instruction in the business, engineering, basic science, health and medical schools in the tertiary education sector. The major state-run universities introduced conventional liberal arts, humanities and social science disciplines to equip the Emirati graduates with diverse skills. Well-planned programs to promote entrepreneurship among Emirati nationals and a festival of thinking are also examples of social engineering with a liberal flavor. According to Jones,

\footnotetext{
... the UAE's leaders hope to convert their citizens many of whom are of Bedouin descent into a new kind of citizen, one who is more modern in the eyes of rulers, more globalization-ready, and better prepared for a post-petroleum era. It is a vision of the citizen as loyal entrepreneurial bourgeois innovative, achievement-oriented, conscientious, civil, tolerant, hard-working, risk taking, businessstarting, community-serving, and patriotic, one who embodies the classic bourgeois virtues, within authoritarian constraints (Jones, 2017, p. 2).
}

The UAE leadership realized early that people's needs had to be fulfilled and their concerns be addressed. They also took a new futuristic approach to capitalize technological innovation in creating public value and making their citizens happy. The Vice President and the Prime Minister of the UAE, Sheikh Mohammed bin Rashid Al Maktoum rightfully emphasized innovation as a means to an end. They ought to deliver their public promises, create values that match people's hopes and outcomes that would instil shared happiness amongst citizens (Al Maktoum, 2013, cited in Rahman and Said, 2015).

As reflected in its long-term strategic goals (i.e. the UAE Vision 2021), the UAE aims to achieve a competitive economy driven by knowledgeable and innovative Emiratis and a diversified and flexible knowledge-based economy powered by skilled Emiratis and strengthened by world-class talent to ensure long-term prosperity for the country. Recently, Sheikh Mohammed Bin Rashid, Vice President and Prime Minister of the UAE and Ruler of Dubai also envisioned UAE to be one of the top innovative countries in the world in the next 
seven years. Central to these aims is the development of human and intellectual capital to promote innovation in UAE's public and private sectors. For the public sector, this means producing high caliber government officers, with (a) the skills to comprehensively develop innovation strategies and policies, and the capability to formulate innovative and workable solutions; and (b) the ability to manage the implementation of those solutions to achieve the intended outcomes (Rahman et al., 2016). In 2014, the UAE Government adopted the National Innovation Strategy 2015 and in February 2018, the UAE Government approved the National Strategy for advanced Innovation. The new strategy is the updated version of the 2014 strategic framework.

Like other social engineering efforts, the UAE political leadership has ventured into Emiratization to bring the Emirati nationals into the mainstream workforce. More specifically, Emiratization is considered as a liberal social engineering project for the following reasons:

First, the lack of entrepreneurial spirit and the reluctance to work in the private sector among the Emiratis can partly be attributed to the generous benefits that the state provides to the Emiratis (Waxin et al., 2018; Al-Waqfi and Forstenlechner, 2012). Similar reservations have also been echoed by private companies (Al-Waqfi and Forstenlechner, 2012). However, the social welfare regime is under scrutiny though complete overhaul is yet to come. The public sector job market is saturated with unemployment among educated Emirati youths increasing.

Second, the government has liberalized the requirement for foreign investors to have Emirati partners and has opened up many sectors where foreign investors can have $100 \%$ ownership (Lawrence et al., 2018). This move is likely to reduce the scope for many Emiratis to earn income from partnerships with expatriates. The old practice of mandatory partnership was a special privilege given by the government to the local Emiratis (Mansour, 2017). Under this situation, unemployed Emiratis may not have many options but to seek jobs in the private sector, which has been made more lucrative through various forms of incentives.

Third, there is a practical necessity of creating a nationalistic zeal among the Emiratis to become active participants in the era of expanded economic opportunities.

\section{Policies and programs}

Three critical institutional interventions such the UAE Vision 2021 (Government of the United Arab Emirates, 2019), the UAE National Innovation Strategy (Government of the United Arab Emirates, 2015) and National Program for Advanced Skills (Government of the United Arab Emirates, 2020) were promulgated at the critical juncture of the UAE's political economy. These documents emphasize self-determination of Emiratis and their skill requirements to lead a future agile government.

\section{The UAE Vision 2021}

The UAE Vision 2021 aims at unlocking the potentials of citizens and enabling them to be a driving force of the UAE's economic development. The Vision summary (Government of the United Arab Emirates, 2010) tells the whole story:

In a strong and safe union, knowledgeable and innovative Emiratis will confidently build a competitive and resilient economy. They will thrive as a cohesive society bonded to its identity, and enjoy the highest standards of living within a nurturing and sustainable environment (emphasis original).

The above summary of the vision spells out the four central tenets of Vision 2021: united in ambition and responsibility, united in destiny, united in knowledge, and united in prosperity. 
While the economic vision is well-articulated and to be materialized through the establishment of a knowledge economy (Ryan, 2016), no less important is the social engineering aspect. Moshashai observes that "behind the hyped economic diversification efforts by the state, lies an implicit social engineering and nation-building project, that is often overlooked but which is key to the overall success of reform in the UAE and the wider GCC" (2018, p. 6).

UAE National Innovation Strategies in 2015 and 2018

The quest for socio-economic transformation and social engineering envisioned in the UAE Vision 2021 was further bolstered with the adoption of the UAE National Innovation Strategy in 2015. UAE political leadership strongly emphasizes that innovation is the future of human investment. It is stated that:

Innovation, research, science and technology will form the pillars of a knowledge-based, highly productive and competitive economy, driven by entrepreneurs in a business-friendly environment where public and private sectors form effective partnerships (Government of the United Arab Emirates, 2015, p. 6).

The innovation strategy framework is built upon three pillars: innovation priority sectors, innovation champions and an innovation-enabling environment. The issue of Emiratization is clearly pronounced in the strategy framework. The strategy emphasizes that:

Given the importance of the citizen in the UAE's development, the NIS focuses on individuals and entrepreneurs who exemplify a spirit of innovation. It appears to empower the nation to drive local innovation by developing innovative national talents and capabilities in science, technology, engineering, mathematics and entrepreneurship, while equipping individuals with the $21^{\text {st }}$ century skills (Government of the United Arab Emirates, 2015, p. 10).

In February 2018, the UAE Government approved the National Strategy for Advanced Innovation. The new strategy is the updated version of the 2015 strategic framework.

\section{National Program for Advanced Skills}

In terms of specific skills, the UAE Government promoted a forward-looking advanced skills portfolio that includes 12 skills to meet the challenges of future government in the UAE (Table 2).

As part of the social engineering model, along with vision and strategies, the UAE Government has implemented numerous policies and programs (Table 3).

\section{Current status and challenges of Emiratization}

While the progress of Emiratization in the public sector is encouraging, it is not satisfactory in the private sector. Toledo (2013) predicted that the Emiratization policy would possibly achieve some level of success in the short-run in an imperfectly competitive market situation, but in the medium-run, a higher level of labor mobility for migrant workers could potentially increase employment opportunities for native workers. In reality, only financial institutions in the private sector have shown positive results. In other areas, the gaps between targets and achievements remain quite high. Though consolidated data are not available, sector-wise data provide glimpses of the gaps that currently persist in the labor market. Banks and insurance companies were the first ones that came under the decree of the government in 1998, which required the implementation of the quota requirement of mandatory intake of 5 percent Emiratis. Over the years, more stringent regulations came into force requiring different kinds of commercial and industrial enterprises to employ a stipulated number of Emiratis. According to a 2016 report of the government, the achievement level of 


\section{PAP \\ 23,2}

180
Skill set

Leadership

Empathy

Growth mindset

Social and cultural awareness Adaptability

Problem solving

Communication Collaboration

Creativity

Scientific literacy

Financial literacy

Tech literacy

Table 2.

Advanced skills in the UAE

\section{Ability}

Ability to effectively manage and inspire a team of people by assigning goals, aligning team members and supporting them in pursuit of those goals

Ability to be aware of others' reactions and understand their behaviour from their point of view

Ability to believe in and pursue self-development through dedication and hard work

Ability to navigate conflict, reconcile differences, and interact with other people in a socially, culturally and ethically appropriate way

Ability to change plans, Mathis's, opinions, or career plans in light of new information, circumstances, or technological advances

Ability to make complex connections as well as identify, analyze, and evaluate situations, ideas, and information to formulate responses and solutions

Ability to listen, understand, convey, and alter information to different audiences Ability to work in a team toward a common goal, adjusting responses to others' actions as needed in order to advance group goals

Ability to imagine and devise new, innovative ways of addressing problems, answering questions. Or expressing meaning through the application, synthesis, or repurposing of knowledge

Ability to use scientific principles to understand one's environment and test hypotheses

Ability to understand and apply conceptual and numerical aspects of finance in practice

Ability to understand. Re and emerging technologies to effectively access and manipulate data and find and share information to enhance learning and working environments

Source: Government of the United Arab Emirates (2020)

Emiratization in the private sector was 3.38 percent and the share of Emirati in the workforce was 7.19 percent (Government of the United Arab Emirates, 2019). Another estimate suggests a slight increase in the number of Emirati women in the workforce (1.5\%).

But on the other hand, the participation rate of Emirati men dropped from 64.1 percent in 2016 to 62.9 percent in 2017. Overall, the rate of increase of Emirati workforce increased by 0.1 percent (Sanderson, 2019). In the backdrop of the slow progress, the UAE Government announced in September 2019 that 18,000 new jobs would be created for Emiratis. Accordingly, the government committed a large amount of money to render training programs (Dhabi, 2019).

About the ongoing challenges in Emiratization, a recent study (Alnaqbi, 2019) reveals both contending and amenable views from selected respondents representing the public sector and private companies. The researcher intended to ascertain the views of five government officials and ten private sector leaders on the impending issues and solicited their ideas for strategies to make the Emiratization policy effective.

While all government respondents noted that the collaboration between the government and the private sector is crucial for the process of Emiratization, they observed that there was little collaboration between them. One respondent indicated that the private sector was inspired by the desire to make a profit and was not really interested in facilitating Emiratization. Another government official noted that private companies prefer hardworking workers from any nationality but are committed to the process of Emiratization. Interestingly, one of the respondents opined that even if the problem of Emiratization was to be solved and that the unemployment levels were to reduce, there would still be a need to import labor because of the high demands of the country's economy. 
Year Details

1980 Federal Law \# 8

MoHRE will have a special department dedicated to find adequate job opportunities for nationals. The department must assist employers in fulfilling their need of national workers whenever needed.

2005 Ministerial Orders 41, 42 and 43 of 2005 impose on private sector employers a quota system, whereby every company with more than 100 employees is obliged to recruit (and retain on the payroll) the stipulated number of UAE nationals to ensure the minimum percentage of participation of Emiratis in the workforce.

Companies with lower grading are required to file mandatory financial guarantees, the amount of which will depend on the category of the employer (as set out in the relevant Order).

2006 Cabinet Resolution on employment of UAE Nationals with special need

- National Human Resource Development and Employment Authority (Tanmia); now a part of MoHRE

- Emirates Nationals Development Programme

- Abu Dhabi Human Resources Authority

- Dubai Government Human Resources Department

- Sharjah Govt. Directorate of Human Resources.

These entities develop the skills of UAE nationals and prepare them for the job market. The entities also serve as recruitment agencies offering a channel for the UAE nationals and employers to reach out to each other.

2009 Cabinet Resolution regulating termination of UAE Nationals working in the private sector

2016 All construction facilities with a workforce of 500 or more employees must appoint at least one Emirati occupational health and safety officer beginning in 2017, the Ministry of Human Resources and Emiratization has announced.

20162016 Companies registered with Tas'heel's online services and employs over 1000 workers will be required to hire Emirati citizens for the 'Data Entry' positions starting 2017, the Ministry of Human Resources and Emiratization announced.

2018 Ministerial Decree No. 519 of 2018 on Regulations and Conditions of Training and Employment of Students

2018 Ministerial Decree No. 212 of 2018 on Regulation of employing nationals in the private sector

2018 Absher is an initiative supervised by Ministry of Presidential Affairs and implemented by MoHRE in order to provide a decent life for UAE citizens. The aim of this initiative is to provide approximately 20,000 jobs for citizens in the coming period.

Under the Absher initiative, the "Discounts and Offers" program aims to support the Emiratis working for the private sector. However, they have to be registered with the Ministry of Human Resources and Emiratization (MoHRE). It's a partnership between the public and private sector. Emiratis are entitled to receive discounts on basic services such as, housing, aviation and insurance.

Source: Government of the United Arab Emirates (2019)

Table 3.

Application of Emiratization: establishment of organizational units, quota and incentives

Importantly, a government officer highlighted the importance of bridging the gap in the technical expertise of Emiratis, especially in the field of science, technology, engineering, and mathematics, while the existing educational trend is to obtain degrees in social sciences. On the other hand, respondents from private organizations indicated that the government ought to understand the needs of the private sector. They also admitted that by and large, the private sector would not understand the needs of the local labor market and so was unable to support Emiratization effectively. Private company executives hoped that the process of absorbing nationals could occur with a solid two-fold plan aiming at improving both the rates of unemployment as well as improving company successes (Alnaqbi, 2019).

For increasing the low-level Emirati interest and absorption in the UAE's private sector, most respondents wanted to see the role of the private sector to communicate with the UAE Government to manage Emiratization in the long term strategically. One of the government leaders recommended oversight from both parties to ensure the smooth progress of the Emiratization process. Conversely, another participant believed that the Emiratization 
PAP

23,2

182

process was a responsibility of all citizens in the country and, hence, private companies should also be involved in the process. Participants in the private sector felt that the government needs to manage human and financial resources by designing effective training programs for the Emirati nationals to improve their skills and employability (Alnaqbi, 2019).

Evidently, for most Emiratis, the public sector is the most preferred option for employment because of the compensation package, holidays, pension, working hours, career, etc. (Ryan, 2016; Al-Ali, 2008; Daleure, 2017; Al-Waqfi and Forstenlechner, 2014). The private sector offers minimal incentives for Emiratis. Because of the flexible labor policy, the private sector has always hired its required workforce from poorer countries with low wages. On top of it, because of poor employee relations and lax labor administration, private sector employers have had relatively relaxed controls over their employees in terms of contract enforcement and dismissal. Private-sector employers are suspicious of the Emirati employees who could be eager to exert both their formal and informal rights. On the other hand, foreign employees have minimum rights, which the employers find much more comfortable to comply with, albeit paying them low salaries for quality performance (Al-Waqfi and Forstenlechner, 2014).

Moreover, a large body of literature identified prevailing cultural norms as deterrents to Emiratis' participation in the private sector (Al-Ali, 2008; Al-Waqfi and Forstenlechner, 2014; Daleure, 2017; Waxin et al., 2018). A case study on Al Futtaim UAE, however, reveals an optimistic picture. The study shows an encouraging growth of culture on the one hand and increasing efficiency displayed by AlFuttaim group in implementing the Emiratization policy. From the Al Futtaim employer perspective, the challenges are associated with perception, expectations, quality of education, human resource systems and policy ownership (Al Khatib, 2016). These challenges call for a comprehensive review of the Emiratization policy outcome. Another study provides a somewhat different reason for the persisting low rate of employment of Emiratis in UAE's private sector - that the business model of private enterprises is usually to increase the profits they can make, which is usually at the expense of the workers (Sherif, 2013, cited in Alnaqbi, 2019).

Contradictory government policies seemingly pose challenges to the Emiratization process. The extremely liberal welfare system of the government for citizenry has played a significant "role in shaping negative attitudes toward employment in the private sector and, in some cases, employment in general. The local population has become heavily dependent on the state; hence they have lost the urge or the need to exploit their full potential" (Kayed and Hassan, 2011, p. 61).

\section{Strategic direction}

It appears that the Emiratization policy is confronted with some complex challenges. These challenges must be addressed and overcome to make the policy successful.

\section{Synchronizing the Emiratization policy with advanced skills}

The British Council UAE report suggests that the new tech-enabled work paradigm already exists in the UAE, affecting every sector. As the Manufacturing Director of Mars (UAE) put it, "being tech-savvy will be an essential skill requirement across all levels, roles and age profiles." The report highlights the widening gap between employer requirements and available skills in the UAE. As much as 40 percent of the employers think lack of skills was the main reason for entry-level job vacancies, while 60 percent observe that new graduates were not adequately prepared for the world of work (British Council, 2018).

As indicated in Table 2, the UAE Government Advanced Skills Framework also needs to be synchronized with the Emiratization policy. In the recently held 'Agile Government Public 
Policy Forum 2020', a number of presentations focused on the need for future employees and leaders to gain new skills. Based on their recent survey among public sector officials in Dubai, Saeed et al. (2020) provided a thorough analysis of the gap between the skills they currently have and what is needed in future.

The British Council report also suggests strong collaboration between educational institutes and employers, as almost 79 percent of respondents in the British Council survey opine this view. It is therefore imperative that in the current age of the 4th industrial revolution, Emiratis need to be equipped with the necessary education and skills to be able to meet the changing demands of jobs in the public and private sectors.

It is promising to see that the National Program for Advanced Skills has already launched the 'Skills Cube' initiative at the Zayed University's main campus in Abu Dhabi. The 'Cube' is part of the 'My Skill 12x12' campaign; it seeks to create new opportunities for employment and excellence in various vital sectors and will include several activities and workshops across the UAE (Government of the United Arab Emirates, 2020). More collaboration is possible involving the industry and private sector into a triple helix space that will promote Emiratization through more action-oriented learning programs.

This type of government-academic collaboration needs to be formalized by updating the Emiratization Law. Adding appropriate clauses to the Emiratization Law may provide a clear direction to the Emirati job seekers to equip themselves with appropriate knowledge and skills needed for the evolving and uncertain future.

\section{Overcoming cultural barriers in the age of globalization}

The future of work in the UAE is undergoing major shifts, driven by not only technological evolution but also globalization. Ongoing global transformations will impact the local workforce and the labor market. In this age of 'globalization' and technological spread, Emirati job seekers should transcend cultural barriers to contribute their knowledge and skills to both government and private sectors by being inclusive agile catalysts. This also calls for a role by the government to revamp local taboos and public value and to cultivate a new pattern of leadership and deft skills amongst the Emiratis. This way, overcoming Emirati job seekers' mindsets could be possible. The enduring commitment from the UAE Government towards its local human capital will facilitate this change.

\section{Policy monitoring}

Adequate policy monitoring by the government may also help address some of these issues and improve the employment conditions for Emiratis in the private sector. The issues need to be addressed by the UAE Government and the private sector collaboratively to ensure that the Emiratization policy agenda makes steady progress in the coming years.

\section{Fostering Public-Private Partnership (PPP)}

The UAE public sector has already opened the door for PPP projects. The promulgation of the Public-Private Partnership (PPP) law 2015 by the Government of Dubai is a big step forward towards exploring possible collaboration between government and industry. PPP can meaningfully focus on widening the opportunities for Emiratis on private sector employment, complying with the Emiratization Law.

\section{Conclusion}

The thrust of Emiratization prompted the UAE Government to adopt social engineering as a tool to connect people with the knowledge-based economy (i.e. a key pillar of the UAE Vision 2021) and to provide them sustained prosperity. This would be challenging in this age of 
disruptive technology, globalization and demographic change. The Emiratization policy journey has shown some remarkable success in terms of accommodating the local human capital in government jobs; however, it remains perplexing in the private sector.

Based on the theoretical understanding of social engineering, this paper aimed to examine the rationales and impact of the process on Emiratization, as well as its pitfalls and future challenges. The implementation of the Emiratization policy has shown positive results in achieving high-level employment of Emiratis in the government sector and enhanced their social and economic profile, but this study also reveals a rather dismal picture on the industry front. This needs a range of actions and understanding by the UAE Government, private sector and academic institutions alike. In this way, the UAE society, which has already attained sustainable prosperity, can be a best practice model for its workforce. The country can work toward the 'UAE Centennial 2071' vision that sets its goal for future generations to live a happier life in a better environment, with bigger opportunities and more robust communication with the world.

\section{References}

Al Khatib, M. (2016), "Emiratization in the private sector: implementation challenges and affects - a case study on Al Futtaim Group, UAE", unpublished capstone report submitted in partial fulfilment for Master of Public Administration Degree, Mohammed Bin Rashid School of Government, Dubai.

Al Maktoum, M.B.R. (2013), The Government Summit: Flashes of Thought, Kuttab Publishing, Dubai.

Alexander, J. and Schimidt, J.K.H.W. (1996), "Social engineering: genealogy of a concept", in Podgórecki, A., Alexander, J. and Shields, R. (Eds.), Social engineering, McGill-Queen's PressMQUP, pp. 1-19.

Alnaqbi, A.M.R. (2019), "Innovation which leads to attract the Emiratization of the youth in the private sector", unpublished dissertation report submitted in partial fulfilment for Master of Innovation Management Degree, Mohammed Bin Rashid School of Government, Dubai.

Al-Ali, J. (2008), "Emiratization: drawing UAE nationals into their surging economy", International Journal of Sociology and Social Policy, Vol. 28 No. 9/10, pp. 365-379.

Al-Waqfi, M.A. and Forstenlechner, I. (2012), "Of private sector fear and prejudice: the case of young citizens in an oil-rich Arabian Gulf economy”, Personnel Review, Vol. 41 No. 5, pp. 609-629.

Al-Waqfi, M.A. and Forstenlechner, I. (2014), "Barriers to Emiratization: the role of policy design and institutional environment in determining the effectiveness of Emiratization", The International Journal of Human Resource Management, Vol. 25 No. 2, pp. 167-189.

British Council, UAE (2018), UAE Future Skills Report 2018, British Council, UAE.

Daleure, G. (2017), Emiratization in the UAE Labor Market. Springer, Singapore.

Davidson, C.M. (2009), "The United Arab Emirates: prospects for political reform”, The Brown Journal of World Affairs, Vol. 15 No. 2, pp. 117-127.

Dhabi, A. (2019), "Sheikh Mohammed's 10 steps for Emiratisation; here's how it affects expats", Khaleej Times, 30 September, available at: https:/www.khaleejtimes.com/news/government/sheikhmohammeds-10-steps-for-emiratisation-heres-how-it-affects-expats- (accessed 12 April 2020).

Federal Competitiveness and Statistics Authority (2018), "Population and social statistics", available at: http://fcsa.gov.ae/en-us/Pages/Statistics/Statistics-by-Subject.aspx\#/\%3Fyear=andfolder=Population $\% 20$ and $\% 20$ Social/Labor $\% 20$ Forceandsubject=Population $\% 20$ and $\% 20$ Social (accessed 11 February 2020).

Government of the United Arab Emirates (2010), "Vision 2021: United Arab Emirates", available at: http://fgccc.org/wp-content/uploads/2016/08/UAE_Vision_2021.pdf (accessed 30 July 2019). 
Government of the United Arab Emirates (2015), UAE National Innovation Strategy, Prime Minister's Office, UAE.

Government of the United Arab Emirates (2018), The UAE \& the World's Leading Economies: Managing Challenges and Opportunities Amidst Global Change, Abu Dhabi Ministry of Planning, Abu Dhabi.

Government of the United Arab Emirates (2019), "Vision 2021 and Emiratization”, available at: https:// www.government.ae/en/information-and-services/jobs/vision-2021-and-emiratisation (accessed 27 March 2019).

Government of the United Arab Emirates (2020), "National Program for Advanced Skills", available at: http://skills.gov.ae/ (accessed 22 February 2020).

Hvidt, M. (2009), "The Dubai model: an outline of key development-process elements in Dubai", International Journal of Middle East Studies, Vol. 41 No. 3, pp. 397-418.

Jones, C.W. (2015), "Seeing like an autocrat: liberal social engineering in an illiberal state", Perspectives on Politics, Vol. 13 No. 1, pp. 24-41.

Jones, C.W. (2017), Bedouins into Bourgeois: Remaking Citizens for Globalization, Cambridge University Press, Cambridge.

Kayed, R.N. and Hassan, M.K. (2011), "Saudi Arabia's economic development: entrepreneurship as a strategy", International Journal of Islamic and Middle Eastern Finance and Management, Vol. 4 No. 1, pp. $52-73$.

Khalid, S. and Sarker, A.E. (2019), "Public management innovations in the United Arab Emirates: rationales, trends and outcomes", Asian Education and Development Studies, Vol. 8 No. 4, pp. 405-415.

Lawrence, J., Debusmann, B. and Hamdan, L. (2018), "UAE law changes provides a new dawn for foreign investors", Arabian Business, 7 June, available at: https://www.arabianbusiness.com/ politics-economics/397987-thurs-uae-law-changes-provides-new-dawn-for-foreign-investors (accessed 12 February 2020).

Mansour, A.M. (2017), "Has the United Arab Emirates federal government succeeded to transform its federal bureaucracy into a new public management system?", International Public Management Review, Vol. 18 No. 1, pp. 116-134.

Mohammed Bin Rashid School of Government (2017), First Look: the UAE and the Future of Work, MBRSG, Dubai.

Moshashai, D. (2018), "National visions as instruments of soft-power in the Gulf Region: the case of the UAE and its' Vision 2021", unpublished doctoral dissertation, Johns Hopkins University, SAIS Europe.

Podgórecki, A., Alexander, J. and Shields, R. (Eds.), (1996), Social Engineering, McGill-Queen's PressMQUP, Canada.

Popper, K. (2012), The Open Society and its Enemies, Routledge, New York, NY.

Rahman, M.H., AlBalooshi, S.A.Y.A. and Sarker, A.E. (2016), "From e-governance to smart governance: policy lessons for the UAE", in Farazmand, A. (Ed.), Global Encyclopedia of Public Administration and Public Policy, Springer, Basel, pp. 1-13.

Rahman, M.H and Said, W.Y. (2015), "Public sector performance and leadership in the United Arab Emirates", presented at the 3rd International Conference on Management, Leadership and Governance (ICMLG 2015), Auckland, New Zealand.

Ryan, J.C. (2016), "Old knowledge for new impacts: equity theory and workforce nationalization", Journal of Business Research, Vol. 69 No. 5, pp. 1587-1592.

Sabry, S. and Zaman, S. (2013), "Emirati unemployment at 14\%", Gulf News, 29 January, available at: https:/gulfnews.com/uae/emirati-unemployment-at-14-1.1139425 (accessed 20 February 2020). 
PAP

23,2

186

Saeed, H., Stephens, M. and Fargher, S. (2020), "Advanced national skills for the user-centric agile public sector", presented at the UAE Public Policy Forum 2020 - Agile Government: Becoming Future-Proof, 17-18 February, Dubai.

Sanderson, D. (2019), "10 charts that paint a picture of Emiratisation", The National, 1 October, available at: https://www.thenational.ae/uae/10-charts-that-paint-a-picture-of-emiratisation-1. 917664 accessed 12 April 2020.

Sherif, S (2013), "Macroeconomic policy, localization and reducing unemployment: the critical human resource issues for the UAE", Competitiveness Review: An International Business Journal, Vol. 23 No. 2, pp. 158-174.

The World Bank (2020), "Country profile: United Arab Emirates", available at: https://databank. worldbank.org/views/reports/reportwidget.aspx?Report_Name=CountryProfileandId=b450fd5 7andtbar $=$ yanddd $=$ yandinf $=$ nandzm $=$ nandcountry $=\overline{A R E}($ accessed 15 February 2020).

Toledo, H. (2013), "The political economy of Emiratization in the UAE", Journal of Economic Studies, Vol. 40 No. 1, pp. 39-53.

United Nations (2020), "Data of the United Arab Emirates", available at: http://data.un.org/en/iso/ae. html (accessed 10 May 2020).

United Nations Development Programme (2019), “2019 Human Development Index ranking”, Human Development Report, available at: http://hdr.undp.org/en/content/2019-human-developmentindex-ranking (accessed 10 May 2020).

Vu, T. (2007), "State formation and the origins of developmental states in South Korea and Indonesia", Studies in Comparative International Development, Vol. 41 No. 4, pp. 27-56.

Waxin, M.F., Lindsay, V., Belkhodja, O., and Zhao, F. (2018), "Workforce localization in the UAE: recruitment and selection challenges and practices in private and public organizations", The Journal of Developing Areas, Vol. 52 No. 4, pp. 99-113.

Yaghi, I. and Yaghi, A. (2014), "Quality of work life in the post nationalization of human resources: empirical examination of workforce Emiratization in the United Arab Emirates", International Journal of Public Administration, Vol. 37 No. 4, pp. 224-236.

Yeung, H.W.C. (2014), "Governing the market in a globalizing era: developmental states, global production networks and inter-firm dynamics in East Asia", Review of International Political Economy, Vol. 21 No. 1, pp. 70-101.

Zafarullah, H. and Huque, A.S. (2012), Managing Development in a Globalized World: Concepts, Processes, Institutions, Routledge, New York, NY.

\begin{abstract}
About the authors
Abu Elias Sarker is an Associate Professor of Department of Management, University of Sharjah, United Arab Emirates. He received his PhD in Public Administration from the University of Liverpool in 1991. Dr. Sarker has researched and published papers on public management reforms, governance, accountability, decentralization and local government in reputed and refereed international journals. Abu Elias Sarker is the corresponding author and can be contacted at: elias@sharjah.ac.ae

Mohammad Habibur Rahman is a Professor at the Mohammed Bin Rashid School of Government in Dubai, United Arab Emirates. He received his PhD from the University of Wales in 1994 and later held two visiting positions, as Senior Fulbright Scholar at Maxwell School of Syracuse University in USA and Visiting Fellow at York Centre for Asian Research of York University in Canada. Prof. Rahman has published papers on governance, civil service reforms, local government, human resource management, e-government and knowledge sharing in top-ranked international journals.
\end{abstract}

For instructions on how to order reprints of this article, please visit our website:

www.emeraldgrouppublishing.com/licensing/reprints.htm

Or contact us for further details: permissions@emeraldinsight.com 